\title{
ЛОКАЛЬНОЕ ГЕОЛОГИЧЕСКОЕ МОДЕЛИРОВАНИЕ КАК ОСНОВА ДЛЯ ПРОЕКТИРОВАНИЯ БОКОВЫХ СТВОЛОВ СКВАЖИН
}

Довгополый В.Н., Шкварок И.Р.

\section{(ЗАО ПГО «Тюменьпрожгеофизика»)}

Резюме. Первым шагом при проектировании нового ствола скважины является создание локальной объемной геолого-геофизической модели залежи, как основы для дальнейших расчетов и построений. Траектория проектного ствола скважины прокладывается по участкам коллектора с улучшенными ФЕС с учетом его насыщения, уровня ВНК и структурных особенностей целевого пласта (пластов), что позволяет качественно оценить перспективную продуктивность скважины уже на стадии проекта.

Предпосылки. Проектирование и сопровождение бурения боковых стволов забойной телесистемой выполняется ЗАО ПГО «Тюменыпромгеофизика» уже давно. С появлением доступных технологий компьютерного объемного геологического моделирования (ПО Petrel) привычная методика была изменена. Первым шагом при проектировании траектории нового ствола скважины является создание локальной объемной геолого-геофизической модели залежи как основы для дальнейших расчетов и построений. Такая модель, построенная по данным ГИС с привлечением сейсмических данных (отражающие горизонты), результатов опробования пластов и проч., является надежным геологическим обоснованием.

Методика работ.

Исходные данные: описание геологического строения месторождения; координаты устъев скважин в единой системе; кривые ГИС; инклинометрия; результаты интерпретации данных ГИС; список принятых мнемоник; петрофизические зависимости, полученные по керновым данным; данные испытаний скважин; структурные карты целевых пластов; карты эффективных толщин; карты текущих и суммарных отборов жидкости; карты текущих пластовых давлений.

1. Подготовительный этап.

1.1. Сбор исходной геолого-геофизической, промысловой, технологической информации. 1.2. Оценка качества всей исходной информации, отбраковка некондиционного материала. 1.3. Взаимная увязка всех карт, скважин, разрывных нарушений. Оцифровка карт. 1.4. Ввод информахии в СУБД FINDER. 1.5. Пересмотр керновых данных, уточнение петрофизических зависимостей. 1.6. При необходимости переинтерпретация данных ГИС. Результатом подготовительного этапа является сводная база данных по участку моделирования в СУБД FINDER, наполненный проект PETREL. модели.

2. Этап построения и проверки качества

2.1. Детальная корреляция разрезов скважин по профилям. 2.2. Структурное моделирование с учетом разрывных нарушений. 2.3. Литофациальный анализ по данньм 3D-сейсмики, керновым данным, электрокаротажным кривым. 2.4. Статистический анализ - выявление вертикальньх и латераль- ных закономерностей распределения фаций, обстановок и циклов осадконакопления. 2.5. Объемное моделирование фаций. 2.6. Статистический анализ - выявление латеральных и вертикальных закономерностей распределения литотитов для различных фаций. 2.7. Объемное моделирование литологии. 2.8. Статистическая проверка качества геологической модели. 2.9. Объемное моделирование петрофизических параметров. 2.10. Статистическая проверка качества многомерной петрофизической модели. Результатом этапа моделирования являются цифровая геологическая модель, развернутый отчет и набор графических приложений.

\section{3. Этап проверки.}

Увязка модели с общей концепцией геологического развития региона, обстановками осадконакопления, гектоническими циклами, положением береговой линия, концепшией геологического строения месторождения. Увязка с данньмм о пластовых флюидах, дебитах, результатах испытаний и прочими данными.

На этом этапе возможно также провести контрольный подсчет запасов для отдельньг блоков месторождения для сравнения его с утвержденными ГКЗ.

4. Этап заложения траскторий боковых

Выбор точек вскрытия пласта, заложение вариантов проектных траекторий боковых стволов. Заказчиком утверждается окончательный вариант траектории бокового ствола.

5. Этап сопровождения бурения.

Бурение ствола с сопровождением забойной телесистемы - запись в режиме реального времени магнитной инклинометрии, ГК. Ввод данных с установленной периодичностью в цифровую геологическую модель. Оперативная корректировка траектории бурящегося ствола.

Выводы. Данная методика отробована нами на месторождениях Западной Сибири и Казахстана. Предварительное построение локальной объемной геолого-геофизической модели как основы для проектирования боковых стволов скважин позволяет существенно снизить риски при бурении; наиболее достоверно контролировать пространственное положение бурящегося ствола относительно проектной траектории, структуры пластов, детального геологического строения залежей; своевременно вводить поправки в направление и режимы бурения. 